\title{
A quantitative appraisal of the ambivalent metal ion binding properties of cytidine in aqueous solution and an estimation of the anti-syn energy barrier of cytidine derivatives
}

\begin{abstract}
The recently defined $\log K_{\mathrm{M}(\mathrm{L})}^{\mathrm{M}}$ versus $\mathrm{p} K_{\mathrm{H}(\mathrm{L})}^{\mathrm{H}}$ straight-line plots for $\mathrm{L}=$ pyridine-type $(\mathrm{PyN})$ and ortho-aminopyridine-type $(o \mathrm{PyN})$ ligands now allow the evaluation in a quantitative manner of the stability of the 1:1 complexes formed between cytidine $(\mathrm{Cyd})$ and $\mathrm{Ca}^{2+}$, $\mathrm{Mg}^{2+}, \mathrm{Mn}^{2+}, \mathrm{Co}^{2+}, \mathrm{Ni}^{2+}, \mathrm{Cu}^{2+}, \mathrm{Zn}^{2+}$ or $\mathrm{Cd}^{2+}\left(\mathrm{M}^{2+}\right)$; the corresponding stability constants, $K_{\mathrm{M}(\mathrm{Cyd})}^{\mathrm{M}}$, including the acidity constant, $K_{\mathrm{H}(\mathrm{Cyd})}^{\mathrm{H}}$, for the deprotonation of the $(\mathrm{N} 3) \mathrm{H}^{+}$site had been determined previously under exactly the same conditions as the mentioned plots. Since the stabilities of the $\mathrm{M}(\mathrm{PyN})^{2+}$ and $\mathrm{M}(o \mathrm{PyN})^{2+}$ complexes of $\mathrm{Ca}^{2+}$ and $\mathrm{Mg}^{2+}$ are practically identical, it is concluded that complex formation occurs in an outersphere manner, and this is in accord with the fact that in the $\mathrm{p} K_{\mathrm{a}}$ range 3-7 metal ion binding is independent of $K_{\mathrm{H}(\mathrm{PyN})}^{\mathrm{H}}$ or $K_{\mathrm{H}(o \mathrm{PyN})}^{\mathrm{H}} \cdot \mathrm{Ca}(\mathrm{Cyd})^{2+}$ and $\mathrm{Mg}(\mathrm{Cyd})^{2+}$ are more stable than the corresponding (outer-sphere) $\mathrm{M}(\mathrm{PyN})^{2+}$ complexes and this means that the $\mathrm{C} 2$ carbonyl group of Cyd must participate, next to N3 which is most likely outer-sphere, in metal ion binding, leading thus to chelates; these have formation degrees of about $50 \%$ and $35 \%$, respectively. $\mathrm{Co}(\mathrm{Cyd})^{2+}$ and $\mathrm{Ni}$ $(\mathrm{Cyd})^{2+}$ show no increased stability based on the $\log K_{\mathrm{M}(o \mathrm{PyN})}^{\mathrm{M}}$ versus $\mathrm{p} K_{\mathrm{H}(o \mathrm{PyN})}^{\mathrm{H}}$ plots; hence, the $(\mathrm{C} 2) \mathrm{O}$ group does not participate in metal ion binding, but the inner-sphere coordination to N3 is strongly inhibited by the $(\mathrm{C} 4) \mathrm{NH}_{2}$ group. In the $\mathrm{M}(\mathrm{Cyd})^{2+}$ complexes of $\mathrm{Mn}^{2+}, \mathrm{Cu}^{2+}, \mathrm{Zn}^{2+}$ and $\mathrm{Cd}^{2+}$, this inhibiting effect on $\mathrm{M}^{2+}$ binding at $\mathrm{N} 3$ is partially compensated by participation of the $(\mathrm{C} 2) \mathrm{O}$ group in complex formation and the corresponding chelates have formation degrees between
\end{abstract}

In honor of Professor Liang-Nian Ji on the occasion of his 70th birthday in friendship and with best wishes.

B. Knobloch · H. Sigel $(\bowtie)$

Department of Chemistry, Inorganic Chemistry,

University of Basel, Spitalstrasse 51,

CH-4056 Basel, Switzerland

E-mail: helmut.sigel@unibas.ch

Tel.: + 41-61-2671007

Fax: + 41-61-2671017 about $30 \%\left(\mathrm{Zn}^{2+}\right)$ and $83 \%\left(\mathrm{Cu}^{2+}\right)$. The different structures of the mentioned chelates are discussed in relation to available crystal structure analyses. (1) There is evidence (crystal structure studies: $\mathrm{Cu}^{2+}, \mathrm{Zn}^{2+}, \mathrm{Cd}^{2+}$ ) that four-membered rings form, i.e. there is a strong $\mathrm{M}^{2+}$ bond to N3 and a weak one to (C2)O. (2) By hydrogen bond formation to $(\mathrm{C} 2) \mathrm{O}$ of a metal ion-bound water molecule, six-membered rings, so-called semichelates, may form. (3) For $\mathrm{Ca}^{2+}$ and $\mathrm{Mg}^{2+}$, and possibly $\mathrm{Mn}^{2+}$, and their Cyd complexes, six-membered chelates are also likely with $(\mathrm{C} 2) \mathrm{O}$ being inner-sphere (crystal structure) and N3 outer-sphere. (4) Finally, for these metal ions also complexes with a sole outer-sphere interaction may occur. All these types of chelates are expected to be in equilibrium with each other in solution, but, depending on the metal ion, either the one or the other form will dominate. Clearly, the cytidine residue is an ambivalent binding site which adjusts well to the requirements of the metal ion to be bound and this observation is of relevance for single-stranded nucleic acids and their interactions with metal ions. In addition, the anti-syn energy barrier has been estimated as being in the order of 6 $7.5 \mathrm{~kJ} / \mathrm{mol}$ for cytidine derivatives in aqueous solution at $25{ }^{\circ} \mathrm{C}$.

Keywords Anti-syn barrier - Cytidine complexes Isomeric equilibria $\cdot$ Nucleic acids $\cdot$ Stability constants

Abbreviations $A D P^{3-}$ adenosine $5^{\prime}$-diphosphate $\cdot A M P^{2-}$ adenosine $5^{\prime}$-monophosphate $\cdot A T P^{4-}$ adenosine $5^{\prime}$-triphosphate $\cdot C D P^{3-}$ cytidine $5^{\prime}$-diphosphate $\cdot c l$ closed $\cdot C M P^{2-}$ cytidine $5^{\prime}$-monophosphate $\cdot 3^{\prime}-C M P^{2-}$ cytidine $3^{\prime}$-monophosphate $\cdot C T P^{4-}$ cytidine $5^{\prime}$ triphosphate $\cdot C y d$ cytidine $\cdot D N A$ deoxyribonucleic acid $\cdot I$ ionic strength $\cdot K_{a}$ acidity constant $\cdot K_{I}$ intramolecular equilibrium constant $\cdot L$ general ligand $\cdot M^{2+}$ general divalent metal ion $\cdot N T P^{4-}$ nucleoside 5 '-triphosphate $\cdot o p$ open $\cdot o P y N$ orthoaminopyridine-type ligand $\cdot P y N$ pyridine-type ligand $\cdot t$-RNA transfer ribonucleic acid $\cdot T u$ tubercidin (7-deazaadenosine) 


\section{Introduction}

The cytosine residue is, along with the adenine, guanine and uracil/thymine moieties, one of the four main nucleobases which occur in RNA or DNA $[1,2]$, where it participates in stacking interactions and hydrogen bonding. Consequently, it is not surprising to find that the structure of DNA double and triple helices is affected, for example, by protonation of N3 of the cytosine moiety [3]. This N3, often considered as a pyridine-type nitrogen $[4,5]$, can also bind metal ions, as is evident, for example, from the crystal structure analysis of yeast phenylalanine transfer ribonucleic acid ( $t$-RNA) $[6,7,8,9]$, which revealed a strong binding of $\mathrm{Pb}^{2+}$ to $\mathrm{N} 3$ and a weaker one to (C2)O. This result is in accord with solution studies which showed that in nucleic acids next to the N7/ (C6)O site of guanine the $\mathrm{N} 3 /(\mathrm{C} 2) \mathrm{O}$ unit of cytosine has the strongest affinity for $\mathrm{Pb}^{2+}[10,11]$ and according to the Stability Ruler of Martin [12, 13, 14] the same order may be surmised for $\mathrm{Zn}^{2+}$.

The ambivalent properties of the cytosine residue are evident from crystal structure studies: (1) in the cis- $\left(\mathrm{NH}_{3}\right)_{2} \mathrm{Pt}\left(3^{\prime}-\mathrm{CMP}\right)_{2}^{2}$ complex $\left(3^{\prime}-\mathrm{CMP}^{2-}=\right.$ cytidine $3^{\prime}$-monophosphate), cis-(N3) ${ }_{2} \mathrm{Pt}$ binding is observed $[15,16]$, whereas (2) in $\mathrm{Ba}(\mathrm{CMP}) \cdot 8.5 \mathrm{H}_{2} \mathrm{O}\left(\mathrm{CMP}^{2-}=\right.$ cytidine $5^{\prime}$-monophosphate) the alkaline earth metal ion is bonded to (C2)O (and the sugar moiety) [15, 17]. Between these two "extremes" are cases (3) where both $\mathrm{N} 3$ and $(\mathrm{C} 2) \mathrm{O}$ participate, e.g. in the tetrakis(1-methylcytosine)copper(II) perchlorate dihydrate [18] the four $\mathrm{N} 3$ atoms of the nucleobases form a $\mathrm{CuN}_{4}$ plane with the more weakly bound $\mathrm{C} 2$ carbonyls above and below this plane.

Considering that biological reactions take place in solution $[1,19,20]$, it is of relevance to know if this ambivalent behavior persists in aqueous solution, especially as in metabolic reactions not only nucleic acids but next to other cytosine derivatives also the nucleotides $\mathrm{CMP}^{2-}$, cytidine $5^{\prime}$-diphosphate $\left(\mathrm{CDP}^{3-}\right)$ and cytidine $5^{\prime}$ triphosphate $\left(\mathrm{CTP}^{4}\right)$ participate [21]. These nucleotides interact with the biologically relevant metal ions (mainly) via their phosphate residues [22, 23, 24, 25] and this interaction determines the stability of these complexes.

A detailed appraisal of the ambivalent properties of the cytosine residue is now possible because straight-line plots of $\log K_{\mathrm{M}(\mathrm{L})}^{\mathrm{M}}$ versus $\mathrm{p} K_{\mathrm{H}(\mathrm{L})}^{\mathrm{H}}$ [27] have recently been determined [26] for simple pyridine-type and also orthoaminopyridine-type ligands (L) like 2-aminopyridine, etc. (see Fig. 1) [28]. This achievement allows a reevaluation of the stability constants of the 1:1 complexes formed between cytidine (Cyd) and the divalent metal ions $\left(\mathrm{M}^{2+}\right) \mathrm{Ca}^{2+}, \mathrm{Mg}^{2+}, \mathrm{Mn}^{2+}, \mathrm{Co}^{2+}, \mathrm{Ni}^{2+}, \mathrm{Cu}^{2+}$, $\mathrm{Zn}^{2+}$ and $\mathrm{Cd}^{2+}$. These constants are defined according to equilibrium 1 and equation 2 :

$$
\mathrm{M}^{2+}+\mathrm{Cyd} \rightleftharpoons \mathrm{M}(\mathrm{Cyd})^{2+}
$$
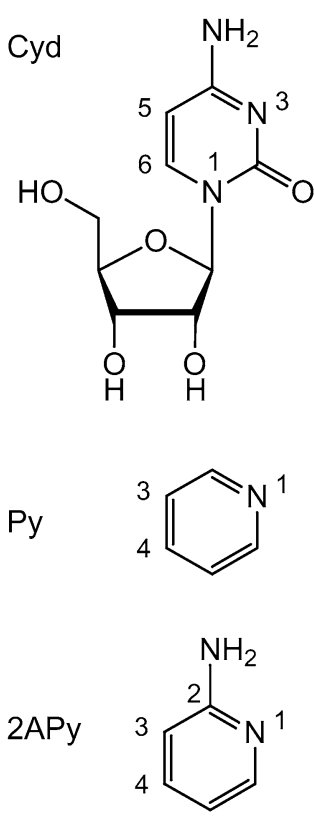

Fig. 1 Chemical structures of cytidine (Cyd), pyridine (Py) and 2aminopyridine (2APy). Cyd is shown in its predominating anti conformation [28]; in the syn conformation the (C2)O group projects onto the ribose ring

$K_{\mathrm{M}(\mathrm{Cyd})}^{\mathrm{M}}=\left[\mathrm{M}(\mathrm{Cyd})^{2+}\right] /\left(\left[\mathrm{M}^{2+}\right][\mathrm{Cyd}]\right)$

They were determined via potentiometric $\mathrm{pH}$ titrations somewhat over 10 years ago in this laboratory [29] under exactly the same experimental conditions as the mentioned straight-line plots (aqueous solutions; $25^{\circ} \mathrm{C} ; I=$ $\left.0.5 \mathrm{M}, \mathrm{NaNO}_{3}\right)[26,29]$. The related acidity constant for the release of the proton from the $(\mathrm{N} 3) \mathrm{H}^{+}$site of $\mathrm{H}(\mathrm{Cyd})^{+}, \quad \mathrm{p} K_{\mathrm{H}(\mathrm{Cyd})}^{\mathrm{H}}=4.24 \pm 0.02 \quad[29], \quad$ is defined according to equilibrium 3 and equation 4 :

$$
\begin{aligned}
& \mathrm{HCyd}^{+} \rightleftharpoons \mathrm{H}^{+}+\mathrm{Cyd} \\
& K_{\mathrm{H}(\mathrm{Cyd})}^{\mathrm{H}}=[\mathrm{H}][\mathrm{Cyd}] /\left[\mathrm{H}(\mathrm{Cyd})^{+}\right]
\end{aligned}
$$

Formerly, approximated straight-line plots for pyridine-type ligands (PyN) had already been used [29], but no corresponding plots for ortho-aminopyridine-type ligands $(o \mathrm{PyN})$ had been available; only the equilibrium constants for $\mathrm{H}$ (tubercidin) ${ }^{+}$and some $\mathrm{M}(\mathrm{Tu})^{2+} \mathrm{com}-$ plexes $[\mathrm{Tu}=$ tubercidin (7-deazaadenosine) $]$ were known [29, 30]. If one considers the structures of the ligands seen in Fig. 1, it is evident that the $o$-amino group is expected [31] to sterically inhibit $\mathrm{M}^{2+}$ binding to the pyridine-N; on the other hand, participation of the carbonyl oxygen $[32,33,34,35]$ at $\mathrm{C} 2$ in complex formation should give rise to an increased complex stability compared to one of the sterically inhibited $\mathrm{M}(o \mathrm{PyN})^{2+}$ complexes. 


\section{Results and discussion}

Qualitative appraisal of the stability of $\mathrm{M}(\mathrm{Cyd})^{2+}$ complexes

For families of structurally related ligands, plots of $\log K_{\mathrm{M}(\mathrm{L})}^{\mathrm{M}}$ versus $\mathrm{p} K_{\mathrm{H}(\mathrm{L})}^{\mathrm{H}}$ result in straight lines [27, 36, 37, 38] and these are defined by Eq. 5:

$\log K_{\mathrm{M}(\mathrm{L})}^{\mathrm{M}}=m \times \mathrm{p} K_{\mathrm{H}(\mathrm{L})}^{\mathrm{H}}+b$

where $m$ represents the slope and $b$ the intercept with the $y$ axis. The parameters for $m$ and $b$, together with the error limits of the values calculated for $\log K_{\mathrm{M}(\mathrm{L})}^{\mathrm{M}}$, where $\mathrm{L}=\mathrm{PyN}$ or $o \mathrm{PyN}$, in the $\mathrm{pH}$ range 3-7 are listed in [26].
Combination of these results [26] with the points due to $\log K_{\mathrm{M}(\mathrm{Cyd})}^{\mathrm{M}}$ and $\mathrm{p} K_{\mathrm{H}(\mathrm{Cyd})}^{\mathrm{H}}$, taken from [29], lead to the plots of Fig. 2.

Several conclusions can immediately be reached. (1) The $\mathrm{M}(o \mathrm{PyN})^{2+}$ complexes of all eight metal ions are less stable than the $\mathrm{M}(\mathrm{PyN})^{2+}$ species. (2) The stabilities of the $\mathrm{M}(o \mathrm{PyN})^{2+}$ and $\mathrm{M}(\mathrm{PyN})^{2+}$ complexes for $\mathrm{Ca}^{2+}$ and $\mathrm{Mg}^{2+}$ differ only little, and in the $\mathrm{pH}$ range 3-7 they are independent of the $\mathrm{p} K_{\mathrm{a}}$ value of the pyridine derivative considered; this indicates [26] that complex formation takes place in an outer-sphere manner. (3) Surprisingly, the $\mathrm{Ca}(\mathrm{Cyd})^{2+}$ and $\mathrm{Mg}(\mathrm{Cyd})^{2+}$ complexes are even more stable than the sterically unhindered $\mathrm{M}(\mathrm{PyN})^{2+}$ species; this proves for these alkaline earth metal ions the importance of the $\mathrm{C} 2$ carbonyl interac-
Fig. 2 Evidence for the varying coordinating properties of cytidine (solid circle) depending on the metal ion involved. This observation is based on the $\log K_{\mathrm{M}(\mathrm{L})}^{\mathrm{M}}$ versus $\mathrm{p} K_{\mathrm{H}(\mathrm{L})}^{\mathrm{H}}$ relationship for simple pyridinetype (open circles) as well as ortho-aminopyridine-type (circled crosses) ligands; the reduced stability of the complexes formed with the latter ligands reflects the steric inhibition due to an orthoamino (or -methyl) group. The least-squares straight-reference lines for the simple pyridinetype ligands are defined by the equilibrium constants for the systems containing (open circles; at the top from left to right): 3-chloropyridine (3ClPy), 4-bromopyridine (4BrPy), 4-(chloromethyl)pyridine (4ClMPy), pyridine (Py),

$\beta$-picoline (= 3-methylpyridine, $3 \mathrm{MPy})$ and 3,5-lutidine $(=3,5-$ dimethylpyridine, 3,5DMPy); and those for the orthoaminopyridine-type ligands by the constants for the systems containing (circled crosses; at the bottom from left to right):

2-methyl-5-bromopyridine (2M5BrPy), 2-amino-5bromopyridine (2A5BrPy), tubercidin $(=7$-deazaadenosine, $\mathrm{Tu}$ ), $\alpha$-picoline (= 2-methylpyridine, 2MPy) and 2-aminopyridine (2APy). All plotted equilibrium constants refer to aqueous solution at $25^{\circ} \mathrm{C}$ and $I=0.5 \mathrm{M}\left(\mathrm{NaNO}_{3}\right)$; the data for Cyd are from [29] and those for the pyridine derivatives from [26]
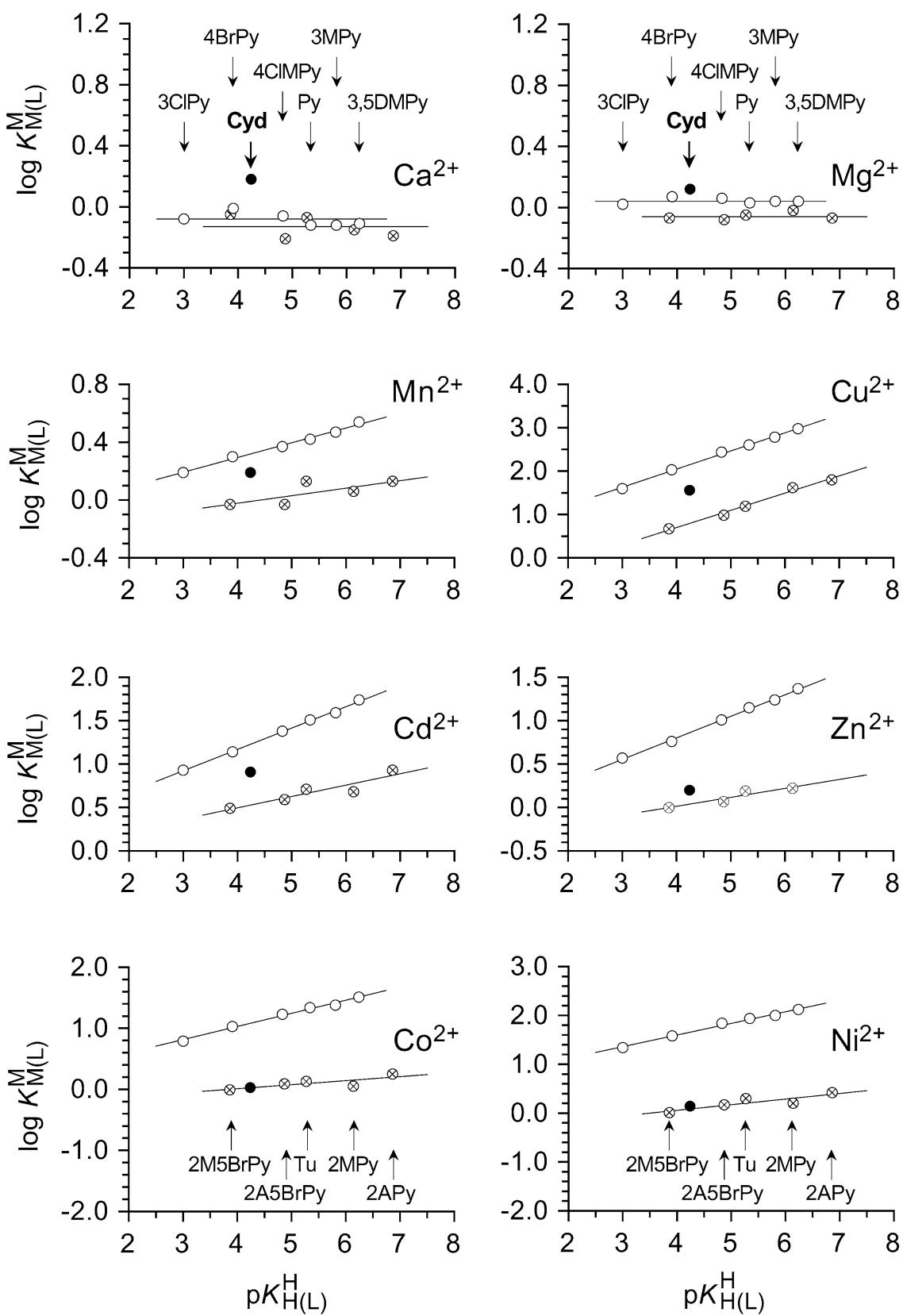
tion. (4) The remaining six $\mathrm{M}(\mathrm{Cyd})^{2+}$ complexes fall in two categories: one where the stability of the complexes corresponds to that of the $\mathrm{M}(o \mathrm{PyN})^{2+}$ species $\left(\mathrm{Co}^{2+}\right.$, $\mathrm{Ni}^{2+}$ ) and another one with stabilities between those of the $\mathrm{M}(o \mathrm{PyN})^{2+}$ and $\mathrm{M}(\mathrm{PyN})^{2+}$ species $\left(\mathrm{Mn}^{2+}\right.$, $\mathrm{Cu}^{2+}, \mathrm{Zn}^{2+}, \mathrm{Cd}^{2+}$ ), where the steric inhibition of the $o$-amino group is evidently in part compensated by a (C2) $\mathrm{O} / \mathrm{M}^{2+}$ interaction.

Quantitative evaluation of the stabilities of the $\mathrm{M}(\mathrm{Cyd})^{2+}$ complexes

Table 1 contains the stability constants determined previously [29] for the $\mathrm{M}(\mathrm{Cyd})^{2+}$ complexes (column 2) together with the calculated stability constants for simple $\mathrm{M}(\mathrm{PyN})^{2+}$ species (column 3) based on $\mathrm{p} K_{\mathrm{H}(\mathrm{Cyd})}^{\mathrm{H}}=$ $\mathrm{p} K_{\mathrm{H}(\mathrm{PyN})}^{\mathrm{H}}=4.24( \pm 0.02) \quad[29]$ and the straight-line parameters given in [26], as well as the stability constants for the $\mathrm{M}(o \mathrm{PyN})^{2+}$ complexes (column 4) resulting from the corresponding calculations for a sterically hindered $o \mathrm{PyN}$ derivative, also with $\mathrm{p} K_{\mathrm{H}(o \mathrm{PyN})}^{\mathrm{H}}=4.24$.

The evaluation of the extent of the steric effect of an $o$-amino group on $\mathrm{M}^{2+}$ binding to a pyridine-type nitrogen with $\mathrm{p} K_{\mathrm{a}}=4.24$ is best done by calculating the differences between the stabilities of the $\mathrm{M}(o \mathrm{PyN})^{2+}$ and $\mathrm{M}(\mathrm{PyN})^{2+}$ complexes (column 2 of Table 2), i.e. $\log K_{\mathrm{M}(o \mathrm{PyN})}^{\mathrm{M}}-\log K_{\mathrm{M}(\mathrm{PyN})}^{\mathrm{M}}$ (Table 1, columns 3 and 4). This difference is zero within the error limits for the two $\mathrm{Ca}^{2+}$ complexes and varies between about -0.1 to $-1.6 \log$ units for the other complexes. This demonstrates that the inhibiting effects of the $o$ amino group for the various metal ions differ significantly and it indicates further, as stated before, that

Table 1 Comparison of the experimentally determined stability constants, $\log K_{\mathrm{M}(\mathrm{Cyd})}^{\mathrm{M}}($ column 2$)$, of some $\mathrm{M}(\mathrm{Cyd})^{2+}$ complexes (Eq. 2) with the stability constants $\log K_{\mathrm{M}(\mathrm{PyN})}^{\mathrm{M}}($ column 3), calculated for the complexes of simple pyridine-type ligands (PyN), and with the constants $\log K_{\mathrm{M}(o \mathrm{PyN})}^{\mathrm{M}}$ (column 4) calculated for the complexes of the sterically inhibited ortho-aminopyridine-type ligands ( $o$ PyN) having the same basicity as $\mathrm{N} 3$ of Cyd (aqueous solution; $\left.25^{\circ} \mathrm{C} ; I=0.5 \mathrm{M}, \mathrm{NaNO}_{3}\right)^{\mathrm{a}, \mathrm{b}}$

\begin{tabular}{llrr}
\hline $\mathrm{M}^{2+}$ & $\log K_{\mathrm{M}(\mathrm{Cyd})}^{\mathrm{M}}$ & $\log K_{\mathrm{M}(\mathrm{PyN})}^{\mathrm{M}}$ & \multicolumn{1}{c}{$\log K_{\mathrm{M}(o \text { PyN })}^{\mathrm{M}}$} \\
\hline $\mathrm{Ca}^{2+}$ & $0.18 \pm 0.06$ & $-0.08 \pm 0.07$ & $-0.13 \pm 0.13$ \\
$\mathrm{Mg}^{2+}$ & $0.12 \pm 0.04$ & $0.04 \pm 0.04$ & $-0.06 \pm 0.06$ \\
$\mathrm{Mn}^{2+}$ & $0.19 \pm 0.08$ & $0.32 \pm 0.02$ & $-0.01 \pm 0.07$ \\
$\mathrm{Co}^{2+}$ & $0.03 \pm 0.08$ & $1.08 \pm 0.03$ & $0.03 \pm 0.08$ \\
$\mathrm{Ni}^{2+}$ & $0.14 \pm 0.12$ & $1.66 \pm 0.03$ & $0.08 \pm 0.10$ \\
$\mathrm{Cu}^{2+}$ & $1.56 \pm 0.06$ & $2.15 \pm 0.04$ & $0.79 \pm 0.07$ \\
$\mathrm{Zn}^{2+}$ & $0.20 \pm 0.11$ & $0.86 \pm 0.02$ & $0.04 \pm 0.08$ \\
$\mathrm{Cd}^{2+}$ & $0.91 \pm 0.07$ & $1.23 \pm 0.02$ & $0.53 \pm 0.09$
\end{tabular}

${ }^{\text {a }}$ The values in column 2 are from [29]; those of columns 3 and 4 were calculated with $\mathrm{p} K_{\mathrm{H}(\mathrm{Cyd})}^{\mathrm{H}}=4.24 \pm 0.02$ [29] and the straightline equations defined in [26]

${ }^{\mathrm{b}}$ The error limits given are three times the standard error of the mean value or the sum of the probable systematic errors, whichever is larger outer-sphere N-binding is important for $\mathrm{Ca}^{2+}$ while inner-sphere $\mathrm{N}$-binding becomes increasingly relevant for the other metal ions and is most likely strongly dominating for $\mathrm{Co}^{2+}, \mathrm{Ni}^{2+}$ and $\mathrm{Cu}^{2+}$. However, for $\mathrm{Mn}^{2+}$ species, both binding modes appear to be in equilibrium with each other; this is also indicated by the small slopes $\left(m_{\mathrm{Mn} / \mathrm{PyN}}=0.102 \pm 0.005\right.$ and $m_{\mathrm{Mn}}$ $\left.{ }_{o \text { PyN }}=0.052 \pm 0.026[26]\right)$ observed for the $\mathrm{Mn}^{2+}$ complexes (see also Fig. 2).

Comparison of the complex stabilities for the $\mathrm{M}(\mathrm{Cyd})^{2+}$ complexes with those of the simple $\mathrm{M}(\mathrm{PyN})^{2+}$ species, i.e. $\log K_{\mathrm{M}(\mathrm{Cyd})}^{\mathrm{M}}-\log K_{\mathrm{M}(\mathrm{PyN})}^{\mathrm{M}}(\mathrm{Ta}-$ ble 2, column 3), confirms the increased stabilities of the $\mathrm{Ca}(\mathrm{Cyd})^{2+}$ and $\mathrm{Mg}(\mathrm{Cyd})^{2+}$ complexes. In none of the other cases is the $\mathrm{C} 2$ carbonyl group able to offset via a $\mathrm{M}^{2+}$ interaction the inhibiting steric effect of the $o$-amino group. The sterically inhibiting effect of an orthocarbonyl group is small, as has been repeatedly concluded [39, 40].

The stability-enhancing effect of the $(\mathrm{C} 2) \mathrm{O}$ group is best seen by comparing the complex stabilities of the $\mathrm{M}(\mathrm{Cyd})^{2+}$ complexes with those of $o$-amino-inhibited $\mathrm{M}(o \mathrm{PyN})^{2+}$ species (Table 1, columns 2 and 4), i.e. by calculating the difference $\log K_{\mathrm{M}(\mathrm{Cyd})}^{\mathrm{M}}-\log K_{\mathrm{M}(o \mathrm{PyN})}^{\mathrm{M}}$ (see column 4 in Table 2). These results demonstrate, in accord with Fig. 2, that there is no stability enhancement within the error limits for the $\mathrm{Co}(\mathrm{Cyd})^{2+}$ and $\mathrm{Ni}(\mathrm{Cyd})^{2+}$ complexes, whereas varying stability enhancements result for the other metal ions, depending on their affinity toward carbonyl oxygens.

Quantification of the extent of participation of the carbonyl group in metal ion binding

The differing involvement of the (C2)O group in metal ion binding may be quantified in the following way. The stability constants for the $\mathrm{M}(o \mathrm{PyN})^{2+}$ complexes

Table 2 Logarithmic differences between the calculated stability constants for $\mathrm{M}^{2+}$ complexes of a pyridine-type ligand (PyN) and an ortho-aminopyridine-type ligand $(o \mathrm{PyN})$ with the same basicity as $\mathrm{N} 3$ in cytidine (column 2), thus quantifying the steric inhibition for an $\mathrm{N} 3$ coordination due to the $(\mathrm{C} 4) \mathrm{NH}_{2}$ group in cytidine. Columns 3 and 4 provide the differences between $\log K_{\mathrm{M}(\mathrm{Cyd})}^{\mathrm{M}}$ and the calculated stability constants $\log K_{\mathrm{M}(\mathrm{PyN})}^{\mathrm{M}}$ and $\log K_{\mathrm{M}(o \mathrm{PyN})}^{\mathrm{M}}$, respectively ${ }^{\mathrm{a}}$

\begin{tabular}{llll}
\hline $\mathrm{M}^{2+}$ & $\begin{array}{l}\log K_{\mathrm{M}(o \mathrm{PyN})}^{\mathrm{M}} \\
-\log K_{\mathrm{M}(\mathrm{PyN})}^{\mathrm{M}}\end{array}$ & $\begin{array}{l}\log K_{\mathrm{M}(\mathrm{Cyd})}^{\mathrm{M}} \\
-\log K_{\mathrm{M}(\mathrm{PyN})}^{\mathrm{M}}\end{array}$ & $\begin{array}{l}\log K_{\mathrm{M}(\mathrm{Cyd})}^{\mathrm{M}} \\
-\log K_{\mathrm{M}(o \mathrm{PyN})}^{\mathrm{M}}\end{array}$ \\
\hline $\mathrm{Ca}^{2+}$ & $-0.05 \pm 0.15$ & $0.26 \pm 0.09$ & $0.31 \pm 0.14$ \\
$\mathrm{Mg}^{2+}$ & $-0.10 \pm 0.07$ & $0.08 \pm 0.06$ & $0.18 \pm 0.07$ \\
$\mathrm{Mn}^{2+}$ & $-0.33 \pm 0.07$ & $-0.13 \pm 0.08$ & $0.20 \pm 0.11$ \\
$\mathrm{Co}^{2+}$ & $-1.05 \pm 0.09$ & $-1.05 \pm 0.09$ & $0.00 \pm 0.11$ \\
$\mathrm{Ni}^{2+}$ & $-1.58 \pm 0.10$ & $-1.52 \pm 0.12$ & $0.06 \pm 0.16$ \\
$\mathrm{Cu}^{2+}$ & $-1.36 \pm 0.08$ & $-0.59 \pm 0.07$ & $0.77 \pm 0.09$ \\
$\mathrm{Zn}^{2+}$ & $-0.82 \pm 0.08$ & $-0.66 \pm 0.11$ & $0.16 \pm 0.14$ \\
$\mathrm{Cd}^{2+}$ & $-0.70 \pm 0.09$ & $-0.32 \pm 0.07$ & $0.38 \pm 0.11$ \\
\hline
\end{tabular}

${ }^{\mathrm{a}}$ All differences are based on the data listed in Table 1; the error limits were calculated according to the error propagation after Gauss 
(Table 1, column 4) represent the monodentate binding of the pyridine nitrogen (N3) of cytidine toward $\mathrm{M}^{2+}$; we define this species as the "open" isomer, $\mathrm{M}(\mathrm{Cyd})_{\mathrm{op}}^{2+}$. The experimentally measured stability constants $K_{\mathrm{M}(\mathrm{Cyd})}^{\mathrm{M}}$ (Eq. 2) are of course overall constants which encompass all $\mathrm{M}(\mathrm{Cyd})^{2+}$ species present in solution, independent of their structure, and including those with a carbonyl interaction. The latter mentioned species are chelates and we define them as "closed", i.e. $\mathrm{M}(\mathrm{Cyd})_{\mathrm{cl}}^{2+}$. One may add that a simple monodentate $(\mathrm{C} 2) \mathrm{O} / \mathrm{M}^{2+}$ binding is highly unlikely because, for example, for $\mathrm{Ca}(\mathrm{Cyd})^{2+}$ and $\mathrm{Mg}(\mathrm{Cyd})^{2+}$ a carbonyl- $\mathrm{M}^{2+}$ interaction must occur but from the properties of the corresponding $\mathrm{M}(\mathrm{PyN})^{2+}$ complexes it is evident that a water molecule is between $\mathrm{N}$ and $\mathrm{M}^{2+}$ (see Fig. 2 and the preceding section: the slope of the straight-reference lines equals zero!); hence, so-called semichelates result. Of course, the interaction could also occur with both sites, N3 and (C2)O, in an outer-sphere manner. In any case, the intramolecular equilibrium 6 :

$\mathrm{M}(\mathrm{Cyd})_{\mathrm{op}}^{2+} \rightleftharpoons \mathrm{M}(\mathrm{Cyd})_{\mathrm{cl}}^{2+}$

exists and its position is quantified by the dimensionless intramolecular equilibrium constant $K_{\mathrm{I}}$ (Eq. 7):

$K_{\mathrm{I}}=\left[\mathrm{M}(\mathrm{Cyd})_{\mathrm{cl}}^{2+}\right] /\left[\mathrm{M}(\mathrm{Cyd})_{\mathrm{op}}^{2+}\right]$

The stability enhancement due to the additional (C2) $\mathrm{O} / \mathrm{M}^{2+}$ interaction is defined by the stability difference expressed in Eq. 8:

$$
\begin{aligned}
\log \Delta & =\log K_{\mathrm{M}(\mathrm{Cyd})}^{\mathrm{M}}-\log K_{\mathrm{M}(\mathrm{Cyd})_{\mathrm{op}}}^{\mathrm{M}} \\
& =\log K_{\mathrm{M}(\mathrm{Cyd})}^{\mathrm{M}}-\log K_{\mathrm{M}(\mathrm{oPyN})}^{\mathrm{M}}
\end{aligned}
$$

These $\log \Delta$ values correspond to the vertical distances in Fig. 2 between the points due to a given $\mathrm{M}(\mathrm{Cyd})^{2+}$ (solid circle) and its reference line (circled crosses) and are listed in column 4 of Table 2.

Previously it has been shown $[27,35,41,42,43]$ that the stability enhancement $\log \Delta$ is interlinked with $K_{\mathrm{I}}$ by Eq. 9:

$K_{\mathrm{I}}=10^{\log \Delta}-1$

Of course, knowledge of $K_{\mathrm{I}}$ allows the calculation of the formation degree of the closed species in equilibrium 6 via Eq. 10:

$\% \mathrm{M}(\mathrm{Cyd})_{\mathrm{cl}}^{2+}=100 \times K_{\mathrm{I}} /\left(1+K_{\mathrm{I}}\right)$

The results for $\log \Delta, K_{\mathrm{I}}$ and $\% \mathrm{M}(\mathrm{Cyd})_{\mathrm{cl}}^{2+}$ are listed in Table 3 (columns 2, 3 and 4).

It needs to be emphasized that the $\mathrm{M}(\mathrm{Cyd})_{\mathrm{cl}}^{2+}$ species are a mixture of several chelated isomers and, among these, four-membered rings may occur if $\mathrm{N} 3$ and $(\mathrm{C} 2) \mathrm{O}$ are both inner-sphere bound (evidence from solid state studies exists for $\mathrm{Cu}^{2+}, \mathrm{Zn}^{2+}$ and $\mathrm{Cd}^{2+}$ species; see Conclusions). By inclusion of a coordinated water, so-called semichelates may form and these now contain a
Table 3 Increased complex stability, $\log \Delta$ (Eq. 6), and extent of chelate formation according to equilibrium 6 for the $\mathrm{M}(\mathrm{Cyd})^{2+}$ systems, as quantified by the dimensionless equilibrium constant $K_{\mathrm{I}}$ (Eqs. 7 and 9) and the percentage of $\mathrm{M}(\mathrm{Cyd})_{\mathrm{cl}}^{2+}($ Eq. 10) (aqueous solution; $\left.25^{\circ} \mathrm{C} ; I=0.5 \mathrm{M}, \mathrm{NaNO}_{3}\right)^{\mathrm{a}}$

\begin{tabular}{llll}
\hline $\mathrm{M}^{2+}$ & $\log \Delta^{\mathrm{b}}$ & $K_{\mathrm{I}}$ & $\% \mathrm{M}(\mathrm{Cyd})_{\mathrm{cl}}^{2+}$ \\
\hline $\mathrm{Ca}^{2+}$ & $0.31 \pm 0.14$ & $1.04 \pm 0.66$ & $51 \pm 16$ \\
$\mathrm{Mg}^{2+}$ & $0.18 \pm 0.07$ & $0.51 \pm 0.24$ & $34 \pm 11$ \\
$\mathrm{Mn}^{2+}$ & $0.20 \pm 0.11$ & $0.58 \pm 0.40$ & $37 \pm 16$ \\
$\mathrm{Co}^{2+}$ & $0.00 \pm 0.11$ & $0.00 \pm 0.25$ & $\sim 0$ \\
$\mathrm{Ni}^{2+}$ & $0.06 \pm 0.16$ & $0.15 \pm 0.42$ & $\sim 0$ \\
$\mathrm{Cu}^{2+}$ & $0.77 \pm 0.09$ & $4.89 \pm 1.22$ & $83 \pm 4$ \\
$\mathrm{Zn}^{2+}$ & $0.16 \pm 0.14$ & $0.45 \pm 0.47$ & $31 \pm 22$ \\
$\mathrm{Cd}^{2+}$ & $0.38 \pm 0.11$ & $1.40 \pm 0.61$ & $58 \pm 11$ \\
\hline
\end{tabular}

${ }^{a}$ For the error limits, see footnotes "b" and "a" of Tables 1 and 2, respectively

${ }^{\mathrm{b}}$ From column 4 of Table 2

six-membered ring with a hydrogen bond. This outersphere interaction may occur with $(\mathrm{C} 2) \mathrm{O}$ if $\mathrm{N} 3$ is inner-sphere, but the reversed situation is likely as well, especially with $\mathrm{Ca}^{2+}$, but also with $\mathrm{Mg}^{2+}$ and $\mathrm{Mn}^{2+}$. In fact, $\mathrm{Ca}^{2+}$-carbonyl interactions are legion and often relatively strong $(2.2-2.3 \AA)$ [44]. Finally, to complete the picture, outer-sphere binding of $\mathrm{M}^{2+}$ to both sites, $\mathrm{N} 3$ and $(\mathrm{C} 2) \mathrm{O}$, is possible to some extent and, indeed, hydrogen bonding is well known for both $(\mathrm{C} 2) \mathrm{O}$ and N3 of the cytosine residue [45].

Clearly, the percentages listed in column 4 of Table 3 encompass all the mentioned "closed" species. For $\mathrm{Co}(\mathrm{Cyd})_{\mathrm{cl}}^{2+}$ and $\mathrm{Ni}(\mathrm{Cyd})_{\mathrm{cl}}^{2+}$ the formation degrees are zero within the error limits, in accord with the conclusions reached in the first section of Results and discussion. However, for all the other $\mathrm{M}(\mathrm{Cyd})^{2+}$ complexes, including those with $\mathrm{Ca}^{2+}, \mathrm{Mg}^{2+}, \mathrm{Mn}^{2+}$ and $\mathrm{Zn}^{2+}$, the formation degrees of the closed species are significant, varying between about $30 \%$ and $50 \%$, and reaching a maximum of about $83 \%$ for $\mathrm{Cu}(\mathrm{Cyd})_{\mathrm{cl}}^{2+}$.

Estimation of the size of the anti-syn energy barrier in cytidine derivatives

The data presented in this work, together with some related earlier results, allow an evaluation of the energy barrier between the anti and synconformations of the cytidine residue (see Fig. 1) by following the route developed earlier [46]. This previous calculation can be repeated with an increased precision because now more reliable stability constants are available for $\mathrm{Cu}(\mathrm{Cyd})^{2+}$ and $\mathrm{Cu}(\text { adenosine })^{2+}$.

The evaluation is based [46] on a comparison of the stabilities of the $\mathrm{Cu}(\mathrm{ATP})^{2-}\left(\log K_{\mathrm{Cu}(\mathrm{ATP})}^{\mathrm{Cu}}=6.34 \pm 0.03\right.$ [46]) and $\mathrm{Cu}(\mathrm{CTP})^{2-}\left(\log K_{\mathrm{Cu}(\mathrm{CTP})}^{\mathrm{Cu}}=6.03 \pm 0.05[46]\right)$ complexes (error limits always $3 \sigma$ ). Since $\mathrm{ATP}^{4}$ (adenosine $5^{\prime}$-triphosphate) exists in solution predominantly in the anti conformation (see Fig. 3) [15, 28, 47], N7 of the adenine residue can be reached by a 

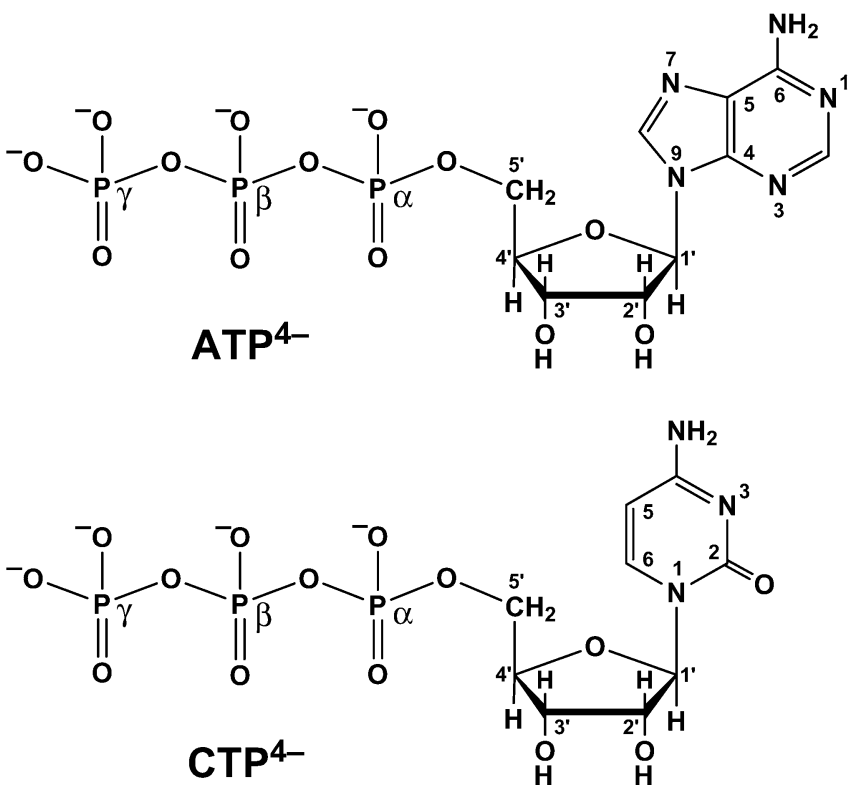

Fig. 3 Chemical structures of adenosine $5^{\prime}$-triphosphate $\left(\mathrm{ATP}^{4-}\right)$ and cytidine $5^{\prime}$-triphosphate $\left(\mathrm{CTP}^{4-}\right)$ in their predominating anti conformations $[15,28,47]$

phosphate-coordinated metal ion and macrochelates according to equilibrium 11 may form [46, 48]:

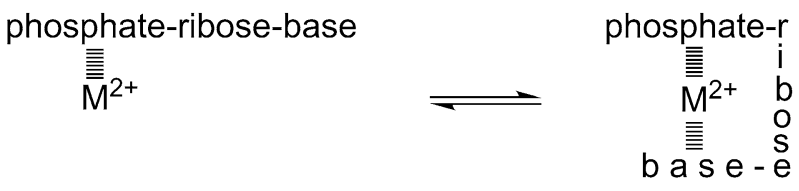

Indeed, macrochelate formation for $\mathrm{Cu}(\mathrm{ATP})^{2-}$ $(67 \pm 3 \%$ [48]) is reflected in an increased complex stability which amounts, based on a pure triphosphate$\mathrm{Cu}^{2+}$ coordination, to $\log \Delta_{\mathrm{Cu} / \mathrm{ATP}}=0.48 \pm 0.04[46$, 48]. This contrasts with the situation in $\mathrm{M}(\mathrm{CTP})^{2-}$ complexes, where N3, the potential binding site, is directed away from the phosphate groups, as is seen in Fig. 3, since in the dominating anti conformation the N1-C6 bond of pyrimidines projects onto or near the ribose ring [47]. This means that for macrochelate formation in $\mathrm{M}(\mathrm{CTP})$ complexes it is necessary to use part (or all) of the $\mathrm{N} 3-\mathrm{M}^{2+}$ interaction energy to turn the anti into the synconformation. Indeed, $\mathrm{Cu}^{2+}$ is the only metal ion, among those studied [46], with a large enough affinity for $\mathrm{N} 3$ to force part of $\mathrm{CTP}^{4}$ in the $\mathrm{Cu}(\mathrm{CTP})^{2-}$ species into a syn conformation. The observed stability increase, $\log \Delta_{\mathrm{Cu} / \mathrm{CTP}}=0.17 \pm 0.06$ [46], corresponds to a formation degree of $32 \pm 9 \%$ for the macrochelate. In fact, the affinity of $\mathrm{Cu}^{2+}$ for $\mathrm{N} 3$ of the cytosine residue is quite pronounced: the stability of $\mathrm{Cu}(\mathrm{Cyd})^{2+}\left(\log K_{\mathrm{Cu}(\mathrm{Cyd})}^{\mathrm{Cu}}=1.56 \pm 0.06\right.$; Table 1$)$ is considerably larger than that of $\mathrm{Cu}$ (adenosine $)^{2+}$ with an N7 coordination $\left(\log k_{\mathrm{Cu}(\mathrm{Ado} / \mathrm{N} 7)}^{\mathrm{Cu}}=0.69 \pm 0.10 ;\right.$ note that here the micro stability constant [5] needs to be used; the error limit is an estimate). Hence, by using the difference between these latter stability constants, $(1.56 \pm 0.06)-(0.69 \pm 0.10)=0.87 \pm 0.12$, and the stability difference between $\mathrm{Cu}(\mathrm{ATP})^{2-}$ and $\mathrm{Cu}(\mathrm{CTP})^{2-}$, which is due to the different extents of macrochelate formation, $\quad(6.34 \pm 0.03)-(6.03 \pm 0.05)=0.31 \pm$ 0.06 , it is possible to estimate the energy barrier between the anti and syn conformations of $\mathrm{CTP}^{4}$. As $\mathrm{ATP}^{4}$ exists predominantly in the anti conformation (Fig. 3), the overall value of $1.18 \pm 0.13 \log$ units $[=(0.87 \pm 0.12)+(0.31 \pm 0.06)]$ represents an estimate for this barrier corresponding to $\Delta G^{\circ}=6.7 \pm 0.7 \mathrm{~kJ} / \mathrm{mol}$ (for the relation between $\Delta G^{\circ}$ and $\log K$, see [35]).

A corresponding evaluation is possible based on the stability constants of $\mathrm{Cu}(\mathrm{AMP}) \quad\left(\log K_{\mathrm{Cu}(\mathrm{AMP})}^{\mathrm{Cu}}=\right.$ $3.17 \pm 0.02 \quad[43])$ and $\mathrm{Cu}(\mathrm{CMP}) \quad\left(\log K_{\mathrm{Cu}(\mathrm{CMP})}^{\mathrm{Cu}}=\right.$ $2.88 \pm 0.09 \quad[49,50])\left(\mathrm{AMP}^{2-}=\right.$ adenosine $5^{\prime}$-monophosphate). The stability enhancement for the $\mathrm{Cu}(\mathrm{AMP})$ complex, $\log \Delta_{\mathrm{Cu} / \mathrm{AMP}}=0.30 \pm 0.06$, reflects a formation degree of the macrochelate of $50 \pm 7 \%$ [43, 50]. In contrast, the stability of the $\mathrm{Cu}(\mathrm{CMP})$ complex is solely determined by the basicity of the phosphate group of $\mathrm{CMP}^{2-}[22,49]$ and, if at all, only traces of macrochelates (Eq. 11) with $\mathrm{N} 3$ are formed. Therefore, our estimate can provide only a lower limit for the energy barrier between the anti and synconformations $[22,49,50]$. By using the above difference between the stabilities of the nucleoside complexes, i.e. $0.87 \pm 0.12$ $\log$ units, as well as the difference between the stabilities of the $\mathrm{Cu}(\mathrm{AMP})$ and $\mathrm{Cu}(\mathrm{CMP})$ complexes, i.e. $(3.17 \pm 0.02)-(2.88 \pm 0.09)=0.29 \pm 0.09, \quad$ one obtains the overall value of $1.16 \pm 0.15 \log$ units $[=(0.87 \pm 0.12)+(0.29 \pm 0.09)]$, which represents the lower limit of the anti-syn energy barrier for $\mathrm{CMP}^{2-}$. By taking into account the error limit, one obtains $1.01 \log$ units and thus $\Delta G^{\circ} \geq 5.8 \mathrm{~kJ} / \mathrm{mol}$ at $25{ }^{\circ} \mathrm{C}$. This limiting value is close to the earlier estimate [46] for this barrier, which was $6 \mathrm{~kJ} / \mathrm{mol}$, and also in excellent agreement with the estimate calculated above.

One may also use the stability constants of $\mathrm{Cu}(\mathrm{ADP})^{-}$ $\left(\log K_{\mathrm{Cu}(\mathrm{ADP})}^{\mathrm{Cu}}=5.61 \pm 0.03\right.$ [43]) and $\mathrm{Cu}(\mathrm{CDP})^{-}([23])$

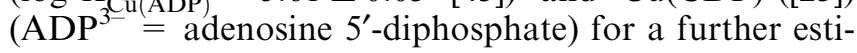
mation. However, although $\mathrm{Cu}(\mathrm{ADP})^{-}$forms macrochelates according to equilibrium 11 [43], one obtains also in this case only a lower limit since the stability of $\mathrm{Cu}(\mathrm{CDP})^{-}$is again solely determined by the basicity of the diphosphate residue [23]. The differences $(5.61 \pm 0.03)-(5.29 \pm 0.08)=0.32 \pm 0.08 \quad$ and $0.87 \pm 0.12$ (see above) result in an overall value of $1.19 \pm 0.14 \log$ units, which provides the lower limit of $1.05 \log$ units and thus $\Delta G^{\circ} \geq 6.0 \mathrm{~kJ} / \mathrm{mol}$.

To conclude (and giving special weight to the evaluation based on the nucleoside $5^{\prime}$-triphosphates), the energy difference between the anti and synconformations of cytidine derivatives in aqueous solution at $25^{\circ} \mathrm{C}$ amounts to about $6-7.5 \mathrm{~kJ} / \mathrm{mol}$. 


\section{Conclusions}

The evaluations presented prove that the cytosine residue is truly an ambivalent liganding site; the type of its interactions in complexes in aqueous solution depends on the metal ion and it is amazing to see how well the presented solution studies are complemented by crystal structure analyses. Therefore, three representative examples referring to $\mathrm{M}^{2+}$ complexes formed with $\mathrm{CMP}^{2-}$ or $\mathrm{dCMP}^{2-}$ are shown in Fig. 4 [17, 51, 52]. In all instances, in agreement with the discussions in the preceding section, the (d)CMP ${ }^{2-}$ ligands are present in the solid state in their more stable anti conformation. Consequently, no macrochelates form; instead, one metal ion coordinates to the phosphate residue and another one to the $\mathrm{N} 3 /(\mathrm{C} 2) \mathrm{O}$ site(s) and thus polymeric structures result in the solids. However, under these circumstances, metal ions may coordinate to the cytosine residue in an unrestricted manner, just as they do in solution to cytidine and thus the following comparisons are possible.

Since the stability constant of the $\mathrm{Co}(\mathrm{Cyd})^{2+}$ complex fits on the reference line defined for $o$-aminopyridinetype binding (Fig. 2), no increased stability is observed (Table 3 ) and consequently no chelates are formed. Thus, one has to conclude that Cyd coordinates via N3 in a monodentate fashion to $\mathrm{Co}^{2+}$. Exactly this binding mode is observed in the solid state (Fig. 4A) where $\mathrm{Co}^{2+}$, with a distorted tetrahedral coordination sphere, forms a strong bond to N3 (1.987 $\AA$ ) and no further interaction with the nucleobase occurs [51, 53]. For $\mathrm{Ni}(\mathrm{Cyd})^{2+}$ also a sole N3- $\mathrm{Ni}^{2+}$ interaction must be surmised, based on the stability data (Fig. 2 and Table 3 ).

The larger $\mathrm{Cd}^{2+}$ is able to form a four-membered ring in Cd(dCMP) $[15,45]$ in the solid state (Fig. 4B), although the $\mathrm{N} 3-\mathrm{Cd}^{2+}$ distance is somewhat shorter $(2.295 \AA)$ than the $(\mathrm{C} 2) \mathrm{O}-\mathrm{Cd}^{2+}$ one $(2.641 \AA)$ [52]. However, a considerably more distorted four-membered ring exists in the solid-state structure of $\mathrm{Zn}(\mathrm{CMP})$, in which $\mathrm{Zn}^{2+}$ is five-fold coordinated (distorted trigonalbipyramidal) [45] with a strong bond to N3 $(2.04 \AA)$ and a rather weak one to $(\mathrm{C} 2) \mathrm{O}(2.69 \AA)$ [54]. Very similar bond lengths are observed in the $\mathrm{Zn}^{2+}$ complexes of the monomethyl phosphate esters of CMP and dCMP [55]. Of course, in solution, equilibria may form with $\mathrm{Cd}(\mathrm{Cyd})^{2+}$ and $\mathrm{Zn}(\mathrm{Cyd})^{2+}$ which also involve semichelates with N3 inner-sphere bound and a water molecule between $\mathrm{M}^{2+}$ and $(\mathrm{C} 2) \mathrm{O}$. In any case, in accord with the bond lengths, chelate formation with nearly $60 \%$ is substantial for $\mathrm{Cd}(\mathrm{Cyd})^{2+}$, whereas it is much less pronounced for $\mathrm{Zn}(\mathrm{Cyd})^{2+}$ with about $30 \%$ only (Table 3 ).

Similarly, in tetrakis(1-methylcytosine)copper(II) perchlorate dihydrate [18] the $\mathrm{N} 3-\mathrm{Cu}^{2+}$ distances are on average $2.026 \AA$, whereas the $\mathrm{C} 2$ oxygens are above and below the $\mathrm{Cu}(\mathrm{N} 3)_{4}$ plane with an average distance of $2.734 \AA$; this means, here again, distorted four-membered rings exist, though the distortion may be less severe because apical interactions of $\mathrm{Cu}^{2+}$ occur a priori
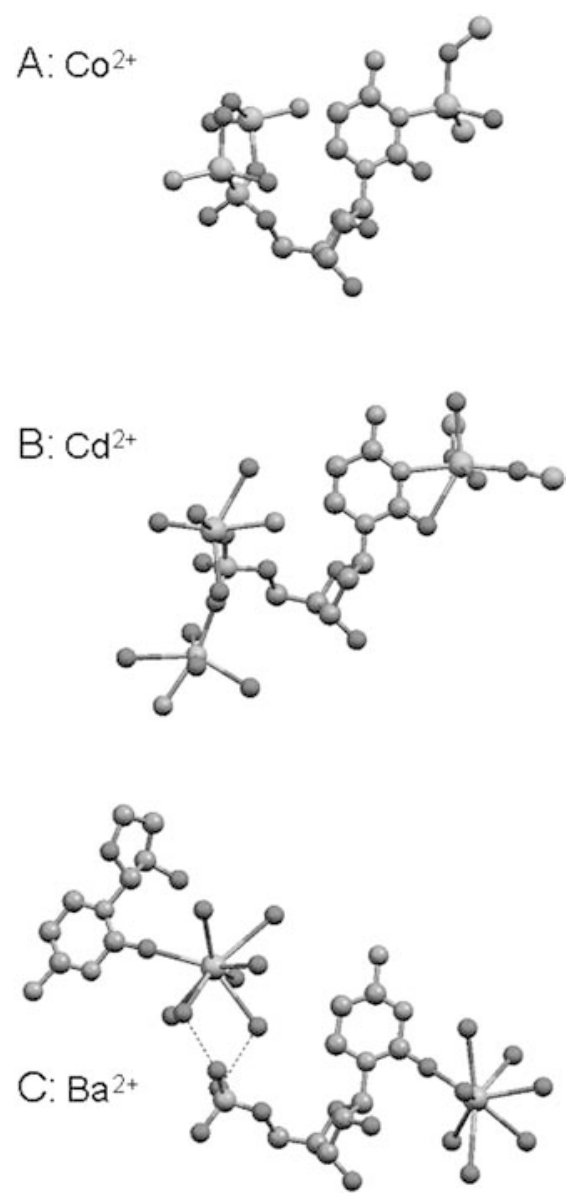

Fig. 4A-C Crystal structures of three metal ion complexes formed with cytidine $5^{\prime}$-monophosphate $\left(\mathrm{CMP}^{2-}\right)$ or $2^{\prime}$-deoxycytidine $5^{\prime}$ monophosphate $\left(\mathrm{dCMP}^{2-}\right)$ exhibiting different metal ion-binding modes. All metal ions in the above structures are represented by somewhat larger balls than the other atoms. In all three structures the cytosine ring shows approximately the same orientation and the crucial metal ion (with other atoms in its coordination sphere) is always located at the right hand side. Oxygen atoms are represented by black balls and hydrogen atoms are omitted for clarity, though in $\mathbf{C}$ two hydrogen bonds are indicated. A In the polymeric Co(CMP) [51] the tetrahedral metal ion is bound to N3 of the cytosine residue (bond length for $\mathrm{N} 3-\mathrm{Co}^{2+}: 1.99 \AA$ ) as well as to two oxygens of phosphate groups and to one water molecule. B In the polymeric Cd(dCMP) [52], binding of the octahedral $\mathrm{Cd}^{2+}$ occurs to both N3 $(2.30 \AA)$ and $(\mathrm{C} 2) \mathrm{O}(2.64 \AA)$; the other four sites are occupied by two oxygens of phosphate groups and two water molecules. C In $\mathrm{Ba}(\mathrm{CMP}) \cdot 8.5 \mathrm{H}_{2} \mathrm{O}[17]$ the octa-coordinated metal ion is inner-sphere bound to (C2)O (2.59 $\AA$ ) and also to seven water molecules which are involved in hydrogen bonding. The coordinates for the structures were downloaded from the Cambridge Structural Database and the structures were drawn with the Mercury 1.1.2 program from the Cambridge Crystallographic Data Centre

in a larger distance and are weaker [56]. Corresponding observations have been made with tetrakis(cytosine)copper(II) perchlorate dihydrate [57], and other $\mathrm{Cu}^{2+}$ complexes of cytosine derivatives as well $[58,59$, $60,61,62]$. Of course, in aqueous solution, $\mathrm{Cu}(\mathrm{Cyd})^{2+}$ may also form a semichelate, N3 being inner-sphere bound, next to the open isomer which occurs in 
equilibrium with a formation degree of $17 \pm 4 \%$ only (Table 3, column 4: 100-83\%).

Another interesting case is $\mathrm{Mn}(\mathrm{CMP})$, for which in the solid state only a rather strong $(\mathrm{C} 2) \mathrm{O}-\mathrm{Mn}^{2+}$ interaction $(2.08 \AA[63])$ was found $[15,45]$; this is clearly responsible for the increased stability (see Fig. 2) of $\mathrm{Mn}(\mathrm{Cyd})^{2+}$, most likely together with an outer-sphere interaction to N3; in accord herewith, chelate formation for $\mathrm{Mn}(\mathrm{Cyd})^{2+}$ amounts to about $35 \%$ (Table 3 ). The suggested outersphere interaction with N3 is further supported by the small slope ( $m=0.052 \pm 0.026$ [26]) observed for the $\mathrm{Mn}^{2+}$ complexes of the $o$-aminopyridine-type ligands (see Fig. 2); such a small slope means that complex stability is nearly independent of the basicity of the $\mathrm{N}$ site and this is indicative for outer-sphere interactions.

In $\mathrm{Ca}(\mathrm{Cyd})^{2+}$ and $\mathrm{Mg}(\mathrm{Cyd})^{2+}$, like in $\mathrm{Mn}(\mathrm{Cyd})^{2+}$, metal ion binding to the $(\mathrm{C} 2) \mathrm{O}$ group leads to an increased stability and a rather pronounced chelate formation of about $35 \%$ and $50 \%$, respectively (Table 3 ). Indeed, the fact that in $\mathrm{Ba}(\mathrm{CMP}) \cdot 8.5 \mathrm{H}_{2} \mathrm{O}$ one of the three $\mathrm{Ba}^{2+}$ ions interacts with the nucleobase via $(\mathrm{C} 2) \mathrm{O}$ $[15,17,45]$ in an inner-sphere manner $(2.59 \AA$ ) (see Fig. 4C) supports the conclusions regarding $\mathrm{Ca}(\mathrm{Cyd})^{2+}$ and $\mathrm{Mg}(\mathrm{Cyd})^{2+}$, for which in solution an additional outer-sphere interaction with N3 is likely, as this would result in a six-membered semichelate (see the third section of Results and discussion). In accord herewith, outer-sphere binding of $\mathrm{Mg}^{2+}$ to N3 of a cytosine residue has been observed in a recent crystal structure analysis of yeast phenylalanine $t$-RNA [64]. However, since outer-sphere binding of $\mathrm{Mg}^{2+}$ to carbonyl oxygens, e.g. of uracil residues $[64,65]$, is also quite common, one may conclude that with $\mathrm{Mg}^{2+}$ and $\mathrm{Ca}^{2+}$ (and possibly with $\mathrm{Mn}^{2+}$ as well) in equilibrium also sole outer-sphere (chelate) complexation occurs.

To conclude, cytosine is clearly a very versatile binding moiety: For metal ions like $\mathrm{Ca}^{2+}, \mathrm{Mg}^{2+}$ and $\mathrm{Mn}^{2+}$ the interaction is expected to occur preferably via (C2)O, whereas for $\mathrm{Co}^{2+}, \mathrm{Ni}^{2+}, \mathrm{Cu}^{2+}, \mathrm{Zn}^{2+}$ and $\mathrm{Cd}^{2+}$ an N3 inner-sphere binding is of relevance; chelates form in all instances except with $\mathrm{Co}^{2+}$ and $\mathrm{Ni}^{2+}$. In other words, the cytosine residue is well prepared by evolution to interact with different metals by adjusting to the preferences of a given ion. This is especially important for single-stranded nucleic acids, where the cytosine unit is known to bind to such diverse metal ions as $\mathrm{Pb}^{2+}$ $[6,7,8,9]$ and $\mathrm{Mg}^{2+}[64]$.

Acknowledgements The competent technical assistance of Mrs Rita Baumbusch and Mrs AstridSigel in the preparation of this manuscript is gratefully acknowledged. This study was supported by the Swiss National Foundation and within the COST D20 programme by the Swiss Federal Office for Education and Science.

\section{References}

1. Sigel A, Sigel H (eds) (1996) Metal ions in biological systems, vol 32: Interactions of Metal Ions with Nucleotides, Nucleic Acids, and their Constituents. Dekker, New York, pp 1-814
2. Sigel A, Sigel H (eds) (1996) Metal ions in biological systems, vol 33: Probing of Nucleic Acids by Metal Ion Complexes of Small Molecules. Dekker, New York, pp 1-678

3. Wu P, Kawamoto Y, Hara H, Sugimoto N (2002) J Inorg Biochem 91:277-285

4. Martin RB (1985) Acc Chem Res 18:32-38

5. Martin RB (1996) Met Ions Biol Syst 32:61-89

6. Rubin JR, Sundaralingam M (1983) J Biomol Struct Dyn $1: 639-646$

7. Sundaralingam M, Rubin JR, Cannon JF (1984) Int J Quantum Chem Quantum Biol Symp 11:355-366

8. Brown RS, Hingerty BE, Dewan JC, Klug A (1983) Nature 303:543-546

9. Brown RS, Dewan JC, Klug A (1985) Biochemistry 24:47854801

10. Sigel H, Da Costa CP, Martin RB (2001) Coord Chem Rev 219-221:435-461

11. Da Costa CP, Sigel H (2000) Inorg Chem 39:5985-5993

12. Martin RB (1986) Met Ions Biol Syst 20:21-65

13. Martin RB (1994) In: King RB (ed) Encyclopedia of inorganic chemistry, vol 4. Wiley, Chichester, pp 2185-2196

14. Martin RB (1994) In: Meyers RA (ed) Encyclopedia of molecular biology and molecular medicine, vol 1. $\mathrm{VCH}$, Weinheim, pp 125-134

15. Aoki K (1996) Met Ions Biol Syst 32:91-134

16. Wu SM, Bau R (1979) Biochem Biophys Res Commun $88: 1435-1442$

17. Hogle J, Sundaralingam M, Lin GHY (1980) Acta Crystallogr Sect B 36:564-570

18. Selvi PT, Murali M, Palaniandavar M, Köckerling M, Henkel G (2002) Inorg Chim Acta 340:139-146

19. Sigel H (2004) Chem Soc Rev 33:191-200

20. Sigel H (1999) Pure Appl Chem 71:1727-1740

21. Rawn JD (1989) Biochemistry. Patterson, Burlington, NC

22. Massoud SS, Sigel H (1988) Inorg Chem 27:1447-1453

23. Sajadi SAA, Song B, Gregáň F, Sigel H (1999) Inorg Chem 38:439-448

24. Sigel H, Tribolet R, Malini-Balakrishnan R, Martin RB (1987) Inorg Chem 26:2149-2157

25. Sigel H (1987) Eur J Biochem 165:65-72

26. Kapinos LE, Sigel H (2002) Inorg Chim Acta 337:131-142

27. Martin RB, Sigel H (1988) Comments Inorg Chem 6:285-314

28. Davies DB, Rajani P, Sadikot H (1985) J Chem Soc Perkin Trans 2 279-285

29. Kinjo Y, Ji L-n, Corfù NA, Sigel H (1992) Inorg Chem 31:5588-5596

30. Ji L-n, Corfù NA, Sigel H (1991) J Chem Soc Dalton Trans $1367-1375$

31. Kapinos LE, Holý A, Günter J, Sigel H (2001) Inorg Chem 40:2500-2508

32. Sigel H, Da Costa CP, Song B, Carloni P, Gregán̆ F (1999) J Am Chem Soc 121:6248-6257

33. Sigel H, Da Costa CP (2000) J Inorg Biochem 79:247-251

34. Da Costa CP, Song B, Gregáň F, Sigel H (2000) J Chem Soc Dalton Trans 899-904

35. Sigel H, Kapinos LE (2000) Coord Chem Rev 200-202:563594

36. Sigel H, Kaden T (1966) Helv Chim Acta 49:1617-1621

37. Sigel H, McCormick DB, Griesser R, Prijs B, Wright LD (1969) Biochemistry 8:2687-2695

38. Sigel H, Wynberg H, van Bergen TJ, Kahmann K (1972) Helv Chim Acta 55:610-613

39. Reily MD, Hambley TW, Marzilli LG (1988) J Am Chem Soc 110:2999-3007

40. Kinjo Y, Tribolet R, Corfù NA, Sigel H (1989) Inorg Chem 28:1480-1489

41. Sigel H, Massoud SS, Tribolet R (1988) J Am Chem Soc 110:6857-6865

42. Sigel H, Massoud SS, Corfù NA (1994) J Am Chem Soc 116:2958-2971

43. Bianchi EM, Sajadi SAA, Song B, Sigel H (2003) Chem Eur J 9:881-892 
44. Einspahr H, Bugg CE (1984) Met Ions Biol Syst 17:51-97

45. Aoki K (1989) In: Saenger W (ed) Landolt-Börnstein, Band 1: Nukleinsäuren, Teilband b: Kristallographischeundstrukturelle Daten II. Springer, Berlin, pp 171-246

46. Sigel H, Tribolet R, Malini-Balakrishnan R, Martin RB (1987) Inorg Chem 26:2149-2957

47. Martin RB, Mariam YH (1979) Met Ions Biol Syst 8:57-124

48. Sigel H, Bianchi EM, Corfù NA, Kinjo Y, Tribolet R, Martin RB (2001) Chem Eur J 7:3729-3737

49. Song B, Feldmann G, Bastian M, Lippert B, Sigel H (1995) Inorg Chim Acta 235:99-109

50. Sigel H, Song B (1996) Met Ions Biol Syst 32:135-205

51. Clark GR, Orbell JD (1978) Acta Crystallogr Sect B 34:18151822

52. Aoki K, Saenger W (1984) J Inorg Biochem 20:225-245

53. Clark GR, Orbell JD (1975) J Chem Soc Chem Commun 697698

54. Aoki K (1976) Biochim Biophys Acta 447:379-381
55. Miller SK, Marzilli LG, Dörre S, Kollat P, Stigler RD, Stezowski JJ (1986) Inorg Chem 25:4272-4277

56. Sigel H, Martin RB (1982) Chem Rev 82:385-426

57. Palaniandavar M, Somasundaram I, Lakshminarayanan M, Manohar H (1996) J Chem Soc Dalton Trans 1333-1340

58. Kistenmacher TJ, Szalda DJ, Marzilli LG (1975) Acta Crystallogr Sect B 31:2416-2422

59. Szalda DJ, Marzilli LG, Kistenmacher TJ (1975) Inorg Chem 14:2076-2081

60. Szalda DJ, Marzilli LG, Kistenmacher TJ (1975) Biochem Biophys Res Commun 63:601-605

61. Szalda DJ, Kistenmacher TJ (1977) Acta Crystallogr Sect B 33:865-869

62. Sundaralingam M, Carrabine JA (1971) J Mol Biol 61:287-309

63. Aoki K (1976) J Chem Soc Chem Commun 748-749

64. Jovine L, Djordjevic S, Rhodes D (2000) J Mol Biol 301:401414

65. Wedekind JE, McKay DB (2003) Biochemistry 42:9554-9563 